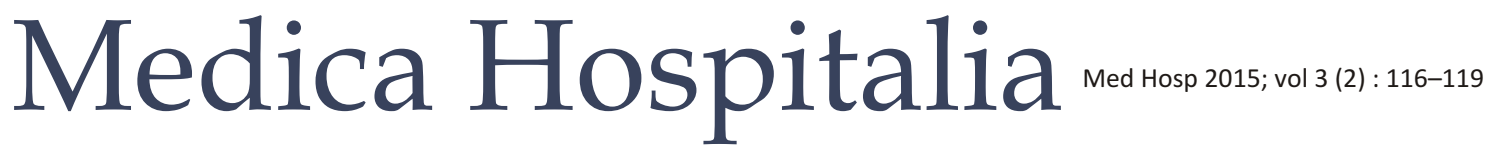

Original Article

\section{Hubungan Antara Tingkat Depresi \\ pada Penderita Kanker Payudara Lanjut Lokal dengan Kadar Kortisol Serum Darah}

\author{
Selamat Budijitno \\ Program Studi PPDS IImu Bedah Onkologi Fakultas Kedokteran Universitas Diponegoro-RS Dr. Kariadi Semarang; \\ Program Studi Magister Epidemiologi Pasca Sarjana Universitas Diponegoro
}

\begin{abstract}
Abstrak
Latar belakang : Stress neurologis, melalui sitokin-sitokin internal di dalam sawar otak akan menyebabkan sekresi kortisol oleh kelenjar adrenal melalui HPA axis. Tujuan penelitian ini adalah membuktikan bahwa terdapat korelasi antara pengaruh depresi terhadap kadar kortisol pada penderita tumor payudara stadium III B.

Metode : Penelitian ini merupakan penelitian klinis CrossSectional, yang dilakukan pada 40 pasien wanita penderita kanker payudara duktal invasif stadium lanjut lokal (stadium IIIA, IIIB, dan IIIC). Tingkat depresi diukur dengan quesioner standar Beck Depression Inventory (BDI). Kadar kortisol dihitung dengan metode ELISA, dan diambil dari serum sampel pada jam 09.0010.00 .

Hasil : Kadar kortisol rerata 254,98; SD 48,65 ng/ml, hasil BDI minimum 4, maksimal 9, dengan median 7. Berdasarkan hasil Spearman corellation terdapat hubungan bermakna antara nilai BDI dengan kadar kortisol ( $p<0,001, r=0,868)$.

Simpulan : Sesuai dengan teori yang ada, kadar kortisol berhubungan erat dengan ekspresi kortisol. Proses sitokin-sitokin internal di otak pada pasien dengan IDC masih berlangsung sesuai teori, tetapi hal ini masih perlu diteliti lebih lanjut lagi. Pada penelitian ini juga terbukti quesioner BDI mempunyai korelasi yang kuat untuk pengukuran tingkat depresi yang dilihat dari parameter kortisol.
\end{abstract}

Kata kunci : kanker payudara, kortisol, skala beck depression inventory

\section{Correlation between of the depression level in patients with locally advanced breast cancer and blood cortisol levels}

\author{
Abstract
}

\begin{abstract}
Background: Neurological Stress, through internal cytokines in the brain barrier will cause secretion of cortisol by the adrenal glands via the HPA axis. The aim is to prove correlation between the effect of depression and cortisol level in patients with stage III B breast cancer.

Methods : This is a Cross-sectional study, performed on 40 women with invasive ductal breast cancer locally advanced (stage IIIA, IIIB, and IIIC). Depression levels measured by standard questionnaires Beck Depression Inventory (BDI). Cortisol levelscalculated by ELISA, and serum samples is taken from 09:00 am to 10:00 am.

Results : Mean of Cortisol level is 254.98; SD $48.65 \mathrm{ng} / \mathrm{ml}$, the result of $\mathrm{BDI}$ minimum 4, maximum 9, with median 7. Based on Spearman test corellation, there is a significant relationship between the value of the BDI with cortisol levels $(p<0.001$, $r=0.868)$.

Conclusion : Cortisol levels are closely related to cortisol expression. The process of internal cytokines in the brain on patients with IDC is still ongoing, but needs to be investigated further. In this study, questionnaires BDI has also proven a strong correlation between level of depression and level of cortisol.
\end{abstract}

Key words : breast cancer, cortisol, beck depression inventory scale 


\section{PENDAHULUAN}

Kanker payudara banyak diderita oleh wanita dan sangat jarangditemukan pada laki-laki. Sekitar 600.000 kasus kanker payudara baru didiagnosa setiap tahun dan 350.000 kasus di antaranya ditemukan di negara maju, sedangkan 250.000 kasus lainnya ditemukan di negara berkembang. ${ }^{1}$ Data Badan Registrasi Kanker Ikatan Ahli Patologi Indonesia (BRK-IAPI) 1994 memperlihatkan bahwa persentase kanker payudara wanita menduduki urutan kedua tertinggi $(11,77 \%)$ setelah kanker rahim $(17,70 \%) .2,3$ Penyakit kanker umumnya dipandang oleh masyarakat sebagai penyakit yang tidak dapat disembuhkan dan berakhir dengan kematian disertai dengan penderitaan hebat, hal ini sangat menimbulkan stress bagi penderitanya. Di samping itu, kanker sendiri secara biologis sudah menimbulkan stress metabolik karena adanya paraneoplastik sindrom. ${ }^{4}$ Respon stres fisiologis dan psikososial dianggap salah satu faktor mediator pada perkembangan kanker. Respon stres secara keseluruhan melibatkan aktivasi beberapa sistem tubuh termasuk sistem saraf otonom dan hipotalamushipofisis-adrenal (HPA) axis. The 'fight or flight' respon ditimbulkan oleh produksi mediator seperti Norepinefrin (NE) dan Epinefrin (E) dari sistem saraf simpatik (SNS) dan medula adrenal. Respon HPA termasuk pelepasan corticotropin-releasing hormon dari hipotalamus, yang menginduksi sekresi hormon adrenocorticotrophic dari hipofisis anterior, yang mengakibatkan dilepaskannya glukokortikoid (GC) seperti kortisol dari korteks adrenal. ${ }^{5}$ Faktor neuroendokrin tambahan juga dilepaskan akibat dari respon terhadap stres, termasuk dopamin, prolaktin, NGF, substansi P dan oksitosin. ${ }^{6,7}$ Kortisol adalah GC manusia yang paling penting. Hal ini penting bagi kehidupan dan mengatur berbagai sistem kardiovaskular penting, metabolisme, imunologi dan fungsi homeostasis. ${ }^{8}$ Kortisol disekresi oleh korteks adrenal dalam menanggapi stres. ${ }^{9,10}$ Kortisol adalah hormon glukokortikoid disintesis dari kolesterol oleh enzim dari P450 keluarga sitokrom di fasciculata zona, wilayah tengah korteks adrenal. Diatur melalui sumbu HPA, kortisol adalah hormon utama yang bertanggung jawab untuk respon stres. Disekresi tertinggi di pagi hari, fungsi utama kortisol adalah untuk mengembalikan homeostasis akibat paparan stres. Efek kortisol adalah sistemik dan berdampak pada mekanisme homeostasis. Sementara target utama kortisol adalah metabolisme, juga mempengaruhi transport ion, dan respon imun. ${ }^{6}$ Pengaktifan HPA axis ini memiliki feedback negatif, di mana ada mekanisme penghambatan sekresi kortisol bila rangsang stress sudah cukup tinggi. ${ }^{11-3}$ Sejumlah penelitian telah menunjukkan bahwa stres dapat mengganggu ritme sirkadian neuroendokrin ${ }^{12}$ dan memicu pertumbuhan tumor serta metastasis. ${ }^{14}$ GC mungkin memiliki efek bimodal, pada dosis rendah, dapat merangsang pertumbuhan tumor, tetapi pada dosis yang lebih tinggi itu menghambat pertumbuhan tumor. ${ }^{15}$ Selain itu, kortisol dapat bertindak secara sinergis dengan katekolamin. Misalnya, efek hormon GC pada proliferasi sel kanker telah dilaporkan bahwa kortisol terbukti mempotensiasi peningkatan akumulasi isoproterenol dalam cAMP. Zhao dan rekan mengamati kortisol dan metabolitnya merangsang pertumbuhan selsel kanker prostat dengan tidak adanya androgen dan meningkatkan sekresi antigen spesifik prostat. ${ }^{16}$ Simon meneliti efek dari beberapa hormon steroid pada sel karsinoma mammae manusia dan menemukan bahwa kenaikan konsentrasi kotisolakan meningkatkan proliferasi sel hampir dua kali lipat. ${ }^{17}$ Peran hormon GC dalam konteks hormon neuroendokrin lainnya masih harus dipelajari berkaitan dengan dampaknya terhadap proliferasi. ${ }^{72}$ Demikian pula, kortisol menstimulai adhesi fibronectin dalam cAMP melaluijalur EPAC-Rap1. ${ }^{18}$ Dengan demikian, hormon stres dapat memicu perlekatan matriks sel dari sel kanker. Stress sangat berpengaruh terhadap imunitas tubuh melalui stimulasi sekresi kortisol dari korteks dan medula adrenal. Kortisol juga berpengaruh terhadap pelepasan noradrenalin dari postganglion simpatik terminal saraf di pembuluh darah dan organ lymfoid. Efeksistemik dari glukokortikoid dan katekolamin ini mempengaruhi pengaturansitokin tipe 1 dan tipe 2. Stress akan menurunkan produksi sitokin tipe 1 yang dibutuhkan dalam respon imunitas seluler terhadap tumor. ${ }^{19}$

Bentuk dari stressor psikis tersebut berupa depresi. Depresi merupakan suatu keadaan yang mempengaruhi tubuh, pikiran, dan perassan serta mempengaruhi pola makan tidur dan mood individu (Hect \& Shiel,2003). Berdasarkan penelitian yang dilakukan oleh Bukberg, Penman and Holland (1984) diketahui bahwa sebanyak 42 dari 62 pasien kanker yang menjalani perawatan di Rumah Sakit mengalami depresi baik berat maupun sedang. Pengukuran depresi dapat dilakukan dengan skoring menggunakan Beck Depression Inventory (BDI). BDI pertama kali diterbitkan pada tahun $1961,{ }^{20}$ terdiri dari 21 pertanyaan tentang bagaimana yang telah dirasakan pada minggu terakhir. Setiap pertanyaan setidaknya memiliki empat tanggapan, urut sesuai intensitas. Konsistensi kuesioner internal untuk BDI baik, dengan koefisien alpha Cronbach sekitar 0,85, yang berarti bahwa item pada inventory sangat berhubungan satu dengan yang lain. ${ }^{21}$ Mengingat pentingnya pengaruh stress terhadap progresifitas kanker, dan apakah stress masih bisa meningkatkan sekresi kortisol pada kelompok individu yang sudah mengalami stress metabolik yang tinggi, maka penelitian ini bertujuan ingin melihat korelasi antara tingkat depresi yang diukur melalui skoring Beck Depression Inventory dengan kadar kortisol darah pada populasi pasien yang telah menderita kanker payudara stadium lanjut lokal. 


\section{METODE}

Penelitian ini merupakan penelitian klinis cross-sectional, yang dilakukan pada 40 pasien wanita penderita kanker payudara duktal invasif stadium lanjut lokal (stadium IIIA, IIIB, dan IIIC). Kriteria inklusi adalah pasien dengan diagnosis karsinoma payudara duktus invasif stadium lanjut lokal, usia berkisar antara 40-60 tahun, menopause, jumlah lekosit $>4000 / \mathrm{mm} 3$, trombosit $\geq 150.000 / \mathrm{mm} 3$, kadar $\mathrm{Hb} \geq 10 \mathrm{mg} / \mathrm{dL}$, dengan kriteria eksklusi mempunyai riwayat gangguan imun/alergi, sedang menjalani terapi hormonal/kortikosteroid, sedang atau sudah dilakukan terapi radiasi, kemoterapi, atau terapi lainnya, menderita penyakit sistemik kronis, DM, Hipertensi, anemia, kelainan jantung, fungsi hepar, dan ginjal, menderita penyakit keganasan lain, status Performance (Karnovsky Index) <60, dan menolak diikutsertakan dalam penelitian.Tingkat depresi diukur dengan quesioner standar Beck Depression Inventory (BDI). Kadarkortisol dihitung dengan metode ELISA, dan diambil dari serum sampel pada jam 09.00-10.00. Dilakukan uji korelasi Spearman's antara skor BDI dengan kadar kortisol darah.

\section{HASIL}

Penelitian ini adalah penelitian klinis yang sudah mendapat persetujuan Ethical Clearance dari Komite Etik Penelitian Kesehatan Fakultas Kedokteran UNDIP-RSUP Dr. Kariadi Semarang. Selama periode penelitian didapatkan 87 pasien dengan karsinoma payudara stadium lanjut lokal. Setelah dilakukan seleksi didapatkan 56 pasien yang memenuhi kriteria inklusi, dari 56 pasien tersebut, 16 pasien di eksklusi. Pasien yang dieksklusi tersebut meliputi 4 pasien dengan riwayat asthma dengan ditemukan wheezing; 6 pasien menderita DM;lima pasien dengan decompensatio cordis NYHA II-III; 3 orang pasien dengan Karnovsky Index kurang dari 60; satu orang menolak masuk dalam penelitian karena alasan penggunaan tambahan terapi herbal; sedangkan 3 orang pasien dieksklusi karena sudah menggunakan terapi alternatif sebelumnya yang tidak jelas kriterianya.

Umur rata-rata seluruh sampel dalam penelitian ini adalah $51,05 \pm 5,70$ tahun. Tingkat pendidikan lulusan SD atau setara $12(30 \%)$ orang, lulusan SMP/sederajat 19 $(47,5 \%)$ orang, dan lulusan SMA atau yang setara 9 (22,5\%)orang. Jenis pekerjaan adalah ibu rumah tangga $16(40 \%)$ orang, dan petani/ buruh tani sebanyak $24(60 \%)$ orang. Nilai rerata Body Mass Index (BMI) dari seluruh sampel adalah $26,36 \pm 2,12$. Klinis status kelenjar getah bening yang positif $35(87,5 \%)$ orang, dan negatif 5 $(12,5 \%)$. Grading histologi dalam penelitian ini adalah grade $16(15 \%)$ orang, grade $218(45 \%)$ orang, sedangkan grade $316(40 \%)$ orang. Status reseptor hormonal dalam penelitian ini $27(67,5 \%)$ reseptor estrogen positif dan $25(62,5 \%)$ reseptor progesteron positif. Reseptor Her-2 yang positif dalam penelitian ini $11(27,5 \%)$ orang. Rerata kadar serum kortisol (mean 254,98; SD 48,65) ng / ml. Skor BDI minimum 4, maksimal 9, dengan median 7 . Berdasarkan hasil analisis dengan Spearman corellation terdapat hubungan bermakna antara nilai BDI dengan kadar kortisol $(p<0,001, \mathrm{r}=0,868)$.

\section{DISKUSI}

Tujuan dari penelitian ini adalah untuk melihat korelasi antara skoring Beck Depression Inventory dengan kadar kortisol dara pada populasi pasien yang menderita kanker payudara stadium lanjut lokal, secara hipotesis diharapkan ada korelasi antara skor BDI dengan kadar kortisol serum. Kami menemukan bahwa terdapat korelasi yang bermakna antara kami eksplorasi moderator dari hubungan ini menunjukkan bahwa hubungan antara skor BDI dengan kadar kortisol serum.

Respon stres manusia melibatkan jalur sinyal yang kompleks antara neuron dan sel-sel somatik. Sementara pemahaman kita tentang interaksi kimia yang mendasari respon stres meningkat jauh dalam beberapa tahun terakhir, masih banyak kurang dipahami. Peran dua hormon peptida, corticotropin-releasing hormone (CRH) dan arginin-vassopressin (AVP) telah dipelajari mempunyai peran yang kuat. Apabila dirangsang oleh stressor lingkungan, neuron di hipotalamus akan mensekresi CRH dan AVP. CRH merupakan polipeptida pendek, diangkut ke hipofisis anterior, yang akan merangsang sekresi kortikotropin. ${ }^{8}$ Akibatnya, hormon corticotropin akan menstimulasi produksi kortikosteroid termasuk kortisol, hormon utama yang langsung berdampak pada respon stres. ${ }^{10} \mathrm{CRH}$ dan vasopresin secara bersamaan mengaktifkan hipotalamus-hipofisisadrenal (HPA) axis. HPA axis terdiri dari sistem interaksi umpan balik antara hipotalamus, kelenjar pituitari, dan kelenjar adrenal. ${ }^{12}$ Hipotalamus melepaskan CRH dan vasopresin, yang mengaktifkan sumbu HPA. CRH merangsang hipofisis anterior untuk melepaskan corticotropin, yang beredar melalui aliran darah ke korteks adrenal, di mana corticoptropin akan meningkatkan produksi kortisol yang akan beredar di seluruh tubuh untuk menyebarluaskan respon stres. ${ }^{10}$ Hal ini masih relevan dengan penelitian-penelitian sebelumnya, bahwa stress akan meningkatkan kortisol, meskipun pada kelompok populasi yang sudah mengalami stress yang cukup tinggi yaitu pada kelompok penderi kanker payudara stadium lanjut.

\section{SIMPULAN}

Dalam kondisi stressor metabolik berat seperti penderita kanker, peningkatan depresi pasien akan meningkatkan titer kortisol darah yang cukup bermakna. Meskipun 
secara teoritik respos stress terhadap peningkatan kortisol diketahui mempunyai umpan balik negatif.

\section{DAFTAR PUSTAKA}

1. Shirley IM, MD. Epidemiologi kanker payudara dan pengendaliannya. Medika 2000;5:326-9.

2. Sugito H. Kanker di Indonesia Tahun 1994 Data Histopatologik. Badan Registrasi Kanker Ikatan Ahli Patologi Indonesia. Dirjen YanMed Dep. Kes RI;1994:3-6.

3. Sarjadi, Trihartini. Cancer registration in Indonesia. Asian Pasific J Cancer Prev, IACR Supplement, 2001; 2: 21-4.

4. Elemkov IJ and Chrousos GP. Stress hormones, Th1/th2 paterns, Pro/Antiinflamatory Cytokines and susceptibility to disease. TEM1999;10(9):359-68.

5. McEwen B. Physiology and neurobiology of stress and adaptation: central role of the brain. Physiol. Rev 2007;87:873-904.

6. Ebner K, Saria A, Singewald N. Substance P in the medial amygdala: emotional stress-sensitive release and modulation of anxiety-related behavior in rats. Proc. Natl Acad. Sci. USA 2004;101:4280-5. RN.

7. Lakshmanan J. Nerve growth factor levels in mouse serum: variations due to stress. Neurochem. Res 1987;12:393-7.

8. Rhen T, Cidlowski J. Anti-inflammatory action of glucocorticoids new mechanisms for old drugs. N. Engl. J. Med 2005;353(16):1711.

9. Chrousos GP, Gold PW. The concepts of stress and stress system disorders. Overview of physical and behavioral homeostasis. JAMA 1992;267(9):1244-52.

10. Sapolsky RM, Romero LM, Munck AU. How do glucocorticoids influence stress responses? Integrating permissive, suppressive, stimulatory, and preparative actions. Endocr. Rev 2000;21(1):55-89.

11. Antoni MH, Cruess S, Cruess DG, et al. Cognitivebehavioral stress management reduces distress and 24-hour urinary free cortisol output among symptomatic HIV-infected gay men. Ann. Behav. Med 2000;22(1):29-37.
12. Sephton S, Spiegel D. Circadian disruption in cancer: a neuroendocrineimmune pathway from stress to disease? Brain Behav. Immun 2003;17(5):321-8.

13. Sephton SE, Sapolsky RM, Kraemer HC, et al. Diurnal cortisol rhythm as a predictor of breast cancer survival. J. Natl Cancer Inst 2000;92(12):994-1000.

14. Schernhammer ES, Laden F, Speizer FE, et al. Night-shift work and risk of colorectal cancer in the nurses' health study. J. Natl Cancer Inst 2003;95(11):825-8.

15. Kawamura A, Tamaki N, Kokunai T. Effect of dexamethasone on cell proliferation of neuroepithelial tumor cell lines. Neurol. Med. Chir. (Tokyo) 1998;38(10):633638. discussion 638-40.

16. Zhao XY, Malloy PJ, Krishnan AV, et al. Glucocorticoids can promote androgen-independent growth of prostate cancer cells through a mutated androgen receptor. Nat. Med 2000;6(6):703-6.

17. Simon $\mathrm{WE}$, Albrecht $\mathrm{M}$, Trams $\mathrm{G}$, et al. In vitro growth promotion of human mammary carcinoma cells by steroid hormones, tamoxifen, and prolactin. J. Natl Cancer Inst 1984;73(2):313-21.

18. Rangarajan S, Enserink JM, Kuiperij HB, et al. Cyclic AMP induces integrin-mediated cell adhesion through Epac and Rap1 upon stimulation of the $\beta 2$-adrenergic receptor. J. Cell Biol 2003;160(4):487-93.

19. Elemkov IJ and Chrousos GP. Stress hormones, Th1/th2 paterns, Pro/AntiinflamatoryCytokines and susceptibility to disease. TEM1999;10(9):359-68.

20. Beck AT, Ward CH, Mendelson M, Mock J, Erbaugh J (June 1961). "An inventory for measuring depression". Arch. Gen. Psychiatry4 (6): 561-71.

21. Ambrosini PJ, Metz C, Bianchi MD, Rabinovich H, Undie A (January 1991). "Concurrent validity and psychometric properties of the Beck Depression Inventory in outpatient adolescents". Journal of the American Academy of Child and Adolescent Psychiatry30 (1): 51-7. 